\title{
CHEMICAL AND BIOLOGICAL INDICATORS FOR EVALUATION OF ARCTIC SOIL DEGRADATION AND ITS POTENTIAL TO REMEDIATION
}

\author{
Tatiana S. SMIRNOVA ${ }^{1}$, Elena A. MAZLOVA ${ }^{1}$, Olga A. KULIKOVA ${ }^{1}$, Ilya M. OSTROVKIN ${ }^{2}$, \\ Adam M. GONOPOLSKY ${ }^{1}$, Kristina V. CHELOZNOVA ${ }^{1}$ \\ ${ }^{1}$ Department of Industrial Ecology, Gubkin Russian State University of Oil and Gas \\ (National Research University), 65 Leninsky Prospekt, 119991 Moscow, Russian Federation \\ ${ }^{2}$ AEG Ingatlanhasznositó Zrt., Lótuszvirág utca 1, 8380 Hévíz, Hungary
}

Received 04 May 2020; accepted 04 December 2020

\begin{abstract}
Highlights
Arctic soils are poorly understood and vulnerable to the natural environment. Low biological activity and high sensitivity to mechanical and chemical effects, for the most part, do not allow them to recover with the human impact on their own. At the same time, the pace of development of the Arctic is growing every year, in addition, as a result of irrational technological interference in this region, there is already a significant "baggage" of accumulated environmental damage. As a result, the extent of degradation of Arctic soils is becoming critical, causing increasing degradation of natural ecosystems.

Currently, the Arctic zone continues to be actively developed, industrial and energy facilities under construction have a negative impact on the soil, subjecting it, first of all, to mechanical destruction.

> Also, the accumulated environmental damage from the illegal disposal and accumulation of various waste is a significant problem of the effect on Arctic soils. The high petroleum and chloride ions content in all soil samples is the result of accumulated environmental damage in research disturbed areas.

In order to develop a complex system of measures to eliminate pollution of the soil of the Arctic zone, it is necessary to research the main characteristics of this object under degradation conditions, as well as to develop a system for monitoring indicators of soil conditions in the Arctic zone.
\end{abstract}

\footnotetext{
Abstract. In recent years, significant efforts have been made to accelerate the economic development of the Arctic zone, leading to intense environmental pollution of this region, accompanied by the significant impact of accumulated environmental damage in the region. The solution to these problems is difficult due to the remoteness of these areas and severe climatic conditions. Therefore, it is important to evaluate the potential for restoration of arctic soils. For this purpose, various indicators are used, including biological ones.

In the analyzed arctic soil samples, high concentrations of petroleum hydrocarbons (up to 47,000 mg/kg) and chloride-ions (0.10-0.14 wt \%) were established. Microbioassay demonstrated a presence of hydrocarbon-oxidizing microorganisms: Penicillium, Azotobacter chroococcum, Bacillus subtilis, Pseudomonas oleovorans.

A low enzymatic activity and specific Arctic climate point out a low self-restoration ability of the soil, demonstrated the need for its remediation.

The microbioassay with microbial strains identification and soil remediation methods suitable for the Arctic zone were recommended.
}

Keywords: arctic, soil quality, oil-contaminated soil, remediation, accumulated environmental damage, environmental monitoring.

*Corresponding author. E-mail: smirnova.ts@gubkin.ru 


\section{Introduction}

The remediation of disturbed components of the natural environment is an important task. To solve it, a comprehensive research of the physico-chemical and biological indicators of contaminated and background compartments is necessary. The results obtained in the study can be used as a base material for the development of measures for monitoring and remediation of the environment.

Being a key-component of the ecological monitoring aims and ecological management in general, a soil quality "can be assessed ... for natural ecosystems where major aims are maintenance of environmental quality and biodiversity conservation" (Bünemann et al., 2018). Traditionally, in sustainable soil management, three groups of soil quality and health indicators are used: physical, chemical and biological soil properties are screened to evaluate soil degradation and pollution (Doran \& Parkin 1996; Lima et al., 2013; Cardoso et al., 2013; Pankhurst et al., 1997). Selection of the indicators shall be based mostly on their sensitivity, reliability and availability while they are required to be easy to interpret (Bünemann et al., 2016).

Given a poor understanding arctic soils, vulnerable to the anthropogenic impact of various origins, the soil quality evaluation is challenging since thresholds have not been set for TPH and number of heavy metals for all regions in AZRF, according to the present Russian environmental law. Study of the arctic soils of different types are necessary prior to develop and implement suitable concept of the arctic soil quality evaluation.

The arctic soils are located in the Far North of Eurasia, namely the Eurasian polar soil-climatic region. These soils are most widespread on the islands of the Arctic Ocean (Novaya Zemlya, the northern part of the Novosibirsk Islands, Franz Josef Land, Severnaya Zemlya), including the northern tip of the Taimyr Peninsula (Khabarov \& Yaskin, 2001).

The arctic soils are formed by separate structural components under detached ridges of lichen-grass-moss vegetation. A significant area of AZRF is covered by plains formed by porous sedimentary rocks: proluvial, glacial, marine, water-glacial. The defining soil-forming processes of arctic soils are insufficient litter formation, humus accumulation, cryogenic structure development and cracking (Mikhailov, 2015).
Gerasko and others researched the change of the chemical indicators of arctic soils with depth (Gerasko et al., 2004). With increasing of soil depth such an indicator as the humus content changes most significantly, while the values of others do not change so much. However, it is this indicator that largely determines the potential for soil self-restoration.

Figure 1 shows the chemical indicators of the soils of AZRF.

It is known that the arctic soil chemical composition along the soil profile is slightly differentiated. The upper soil layers are characterized by the accumulation of oxalate-soluble forms of $\mathrm{Fe}_{2} \mathrm{O}_{3}$ ("ironization") (Stoops, 2003). A neutral or slightly acidic reaction ( $\mathrm{pH} \mathrm{6.4-6.8)}$ of the soil medium is typical with slight variations in its lower horizons. A humus content in the arctic soils is small and ranges from 1 to 5\% (Jenkinson et al., 1991). The arctic soil pedogenesis in carbonate rocks contributes to the formation of free carbonates. The soil absorbing complex is almost completely represented by bases (Lebedeva-Verba \& Gerasimova, 2009).

Low biological activity and high sensitivity to adverse mechanical and chemical effects inhibit a self-restoration of arctic soils. Meanwhile, against the current Arctic economic growth, the problem of the elimination of the accumulated environmental damage has not been resolved yet. As a result, the extent of degradation of arctic soils is becoming critical, causing increasing degradation of natural ecosystems (Medvedeva \& Vakula, 2016).

Among the key elements polluting the arctic soil, in addition to oil and oil products, heavy metals can be identified. Among the main metal toxicants in soils, heavy metals and metalloids such as manganese, zinc, and lead are common (Vishnevaya, 2016; Kulikova, 2019). Prior to evaluate the arctic soil degradation and pollution, organic carbon, $\mathrm{PAH}$ and oil content as the chemical indicators and an enzymatic activity as the biological indicators are employed for oil-polluted arctic soils (Beyer et al., 2000). Also, it is deemed to be environmentally safe to use resident species for the bioremediation purposes, promoting the bacterial community composition in the polluted soils to be studied (Ferguson et al., 2020). It is known that oil-pollution is often accompanying by soil salinization. Moreover, several studies report the inhibition of bioremediation processes in

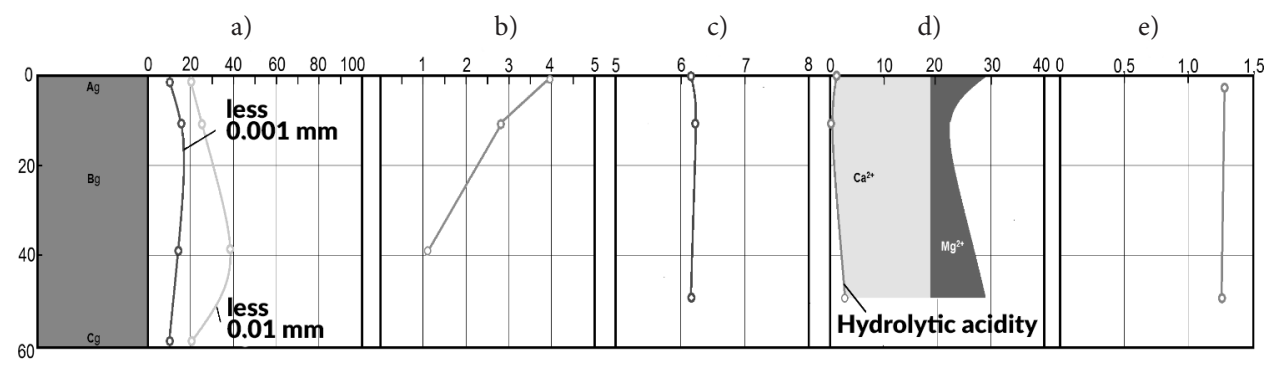

Figure 1. Chemical indicators of arctic soils, where (a) is the particle size distribution of the fraction, \%, (b) is humus, \%, (c) is aqueous $\mathrm{pH},(\mathrm{d})$ is the exchange base, hydrolytic acidity, mmol (equiv.) $100 \mathrm{~g}$ of soil, (e) is oxalate-soluble forms of $\mathrm{Fe}_{2} \mathrm{O}_{3} \%$ per calcined sample (source: Gerasko et al., 2004 with author's additions) 
oil-polluted arctic soils with high salinity (Rhykerd et al., 1995; Chang et al., 2018; Wang et al., 2017).

Therefore, prior to developing an integrated system of measures to eliminate soil pollution in the Arctic zone, it was necessary to evaluate the self-restoration potential of disturbed arctic soils by analyzing chemical and biological indicators.

\section{Material and methods}

\subsection{Study area}

The arctic tundra soil samples were taken during an expedition to the terrestrial area nearby the Cape Kamenny coast, Yamal-Nenets autonomous district of the Russian Federation. The soil samples were collected at the area with visible oil-pollution; a background soil sampling was conducted on the top of the closely spaced hill with no traces or sources of pollution observed. Table 1 provides a brief description of the arctic soil samples selected to analyze. The soil samples were taken at various depths to determine the degree of the arctic soil degradation due to a vertical migration of toxicants (USSR State Committee for Standards, 1989).

Table 1. Characteristics of the studied samples

\begin{tabular}{|c|l|}
\hline Sample & \multicolumn{1}{|c|}{ Characteristics } \\
\hline 1 & $\begin{array}{l}\text { depth of selection: } 0-30 \mathrm{~cm} \text {; sample weight } 1.5 \mathrm{~kg} ; \\
\mathrm{pH}=5.7-6.0 ; \\
\mathrm{t} \text { soil }=+14^{\circ} \mathrm{C} \text {; no vegetation; oil pollution } \\
\text { detected }\end{array}$ \\
\hline 2 & $\begin{array}{l}\text { depth of selection: } 20-40 \mathrm{~cm} \text {; sample weight } \\
0.4 \mathrm{~kg} ; \mathrm{pH}=6.4 ; \\
\mathrm{t} \text { soil }=0{ }^{\circ} \mathrm{C} \text {; no vegetation; oil pollution detected }\end{array}$ \\
\hline 3 & $\begin{array}{l}\text { depth of selection: } 0-20 \text {; sample weight } 0.5 \mathrm{~kg} ; \\
\mathrm{pH}=5.3-5.7 ; \\
\mathrm{t} \text { soil }=+16^{\circ} \mathrm{C} \text {; no vegetation; oil pollution } \\
\text { detected }\end{array}$ \\
\hline $\begin{array}{l}\text { Back- } \\
\text { ground } \\
\text { soil }\end{array}$ & $\begin{array}{l}\text { depth of selection: } 0-30 \mathrm{~cm} \text {; sample weight } 1.5 \mathrm{~kg} ; \\
\mathrm{pH}=5.8-6.2 ; \\
\mathrm{t} \text { soil }=+12^{\circ} \mathrm{C}\end{array}$ \\
\hline
\end{tabular}

\subsection{Samples analysis}

For laboratory research samples of oil-contaminated arctic soil were prepared according to standard methods (USSR State Committee for Standards, 1989). Samples of moist arctic soil were dried at the room temperature for 24 hours to an air-dry state and mechanically purified from plant and other impurities. The dried soil samples were grinding in a porcelain mortar and sifting through a sieve with a hole diameter $\mathrm{d}=1.0 \mathrm{~mm}$ (USSR State Committee for Standards, 1984).

To determine the fraction of chloride-ions, an aqueous extract from the soil was prepared (USSR State Committee for Standards, 1985). An aliquot of the aqueous extract was placed to a flask with sequent adding distilled water up to $30 \mathrm{~mL}$ of total volume and $1 \mathrm{~mL}$ of $10 \mathrm{wt} \% \mathrm{~K}_{2} \mathrm{CrO}_{4}$. The solution is titrated by $0.02 \mathrm{~mol} / \mathrm{L} \mathrm{AgNO}_{3}$.
The prepared soil was weighted to $0.5 \mathrm{~g}(\mathrm{dw})$ for polluted samples and to $5 \mathrm{~g}(\mathrm{dw})$ - for background sample. The soil samples were extracted with $30 \mathrm{~mL}$ of $\mathrm{CCl}_{4}$, and the extract aliquot was cleaned up, using column chromatography with $1.0 \mathrm{~g}$ of $\mathrm{Al}_{2} \mathrm{O}_{3}$ as a solid phase. The eluate was collected and brought to $25 \mathrm{~mL}$. Quantitative analysis (IR spectrometer AN-2, Russia) of TPH was carried out by IR spectrometry (USSR State Committee for Standards, 1998).

Prior to estimating the soil enzymatic activity as a crucial indicator of the adverse effect of pollutants on the soil properties, especially sensitive to oil-pollution oxidoreductase (catalase and dehydrogenase) enzymes were chosen. The catalase activity was evaluated, using gasometry of $\mathrm{O}_{2}$ formation after adding $5 \mathrm{~mL}$ of $3 \% \mathrm{H}_{2} \mathrm{O}_{2}$ to $1 \mathrm{~g}$ of soil sample mixed with $0.1 \mathrm{~g}$ of $\mathrm{CaCO}_{3}$. The dehydrogenase activity was determined: $2 \mathrm{~mL}$ of $0.5 \%$ 2,3,5-triphenyltetrazolium chloride was added to $1 \mathrm{~g}$ of air-dried soil sample. The suspension was separated by centrifugation (3,000 rpm, $5 \mathrm{~min})$ after being thermostatically stated at $30^{\circ} \mathrm{C}$ for $24 \mathrm{~h}$. The supernatant was decanted, and $7.5 \mathrm{~mL}$ of acetone was added to the bottom soil in the centrifuge vial to extract 2,3,5-triphenylformazan formed. The coloured supernatant was analysed by photometry with wavelength $440 \mathrm{~nm}$.

The rate of carbon dioxide $\left(\mathrm{CO}_{2}\right)$ release from the soil indirectly characterizes its biological activity, since the basic quantity of $\mathrm{CO}_{2}$ is released due to the processes of mineralization of organic substances. Hence, the determination of soil respiration also was carried out (Kozlova, 2005).

This method is based on the neutralization of $\mathrm{CO}_{2}$ released during soil respiration by an alkali solution and the subsequent titration of the resulting potassium carbonate solution with hydrochloric acid using phenolphthalein as an indicator. The experiment was conducted during one month to establish the degree of soil self-restoration for a specified period. For a month, the soil samples were at a temperature of $+22{ }^{\circ} \mathrm{C}$ under aerobic conditions with an air humidity of $45 \%$.

Microbiological analysis was carried out by the method of sowing aqueous soil extracts on solid nutrient media (Guidelines for sanitary-microbiological soil research, 1976). $1 \mathrm{~mL}$ of the analyzed material was sowed in Petri dishes with a meat-and-peptone agar as a dense nutrient medium. During subsequent cultivation of the inoculum in the thermostat at a temperature of $+22^{\circ} \mathrm{C}$, a colony is formed from each cell as a result of reproduction, and their number is counted.

The analysis can be used as a diagnostic one in the research of soil characteristics, since some microorganisms are indicators of oil pollution and respond to the soil system pollution by changing their quantitative and qualitative composition.

All tests were run in duplicates/triplicates; processing the results of laboratory studies was carried out using MS Excel. 
Table 2. The results of determination of chloride-ions in arctic soil samples

\begin{tabular}{|c|c|c|}
\hline Sample & $\begin{array}{c}\text { The amount of silver } \\
\text { nitrate used for titration, } \\
\text { mL }\end{array}$ & $\begin{array}{c}\text { The fraction of } \\
\text { chloride ions, } \\
\text { wt } \%\end{array}$ \\
\hline 1 & 2.93 & 0.10 \\
\hline 2 & 3.90 & 0.14 \\
\hline 3 & 3.23 & 0.11 \\
\hline $\begin{array}{l}\text { Back- } \\
\text { ground } \\
\text { soil }\end{array}$ & 2.4 & $<0.01$ \\
\hline
\end{tabular}

Table 3. The results of the TPH analysis of the arctic soil samples

\begin{tabular}{|c|c|}
\hline Sample & Petroleum concentration, $\mathrm{mg} / \mathrm{kg}$ soil \\
\hline 1 & 29,490 \\
\hline 2 & 13,065 \\
\hline 3 & 47,100 \\
\hline Background soil & 84 \\
\hline
\end{tabular}

\section{Results}

The soil samples were analyzed in the laboratory conditions, aiming to evaluate chloride-ion and total petroleum hydrocarbon concentrations, an enzymatic activity (catalase, dehydrogenase), soil respiration, and microbiological composition of the soils.

The results of determining the fraction of chloride ions are shown in Table 2.

The results of determining the petroleum concentration in samples of arctic soil are shown in Table 3.

The content of chlorides and petroleum content in arctic soil samples is significantly higher than in the background sample.

The results of determining the enzymatic activity of arctic soil samples are shown in Table 4.

Table 4. The results of determination of the enzymatic activity of the arctic soil samples

\begin{tabular}{|c|c|c|c|c|}
\hline \multirow{2}{*}{ Sample } & \multicolumn{2}{|c|}{$\begin{array}{c}\text { The activity of soil } \\
\text { catalase, } \\
\mathrm{mL} \mathrm{O}_{2} / \mathrm{min} / \mathrm{g} \text { soil }\end{array}$} & \multicolumn{2}{c|}{$\begin{array}{c}\text { The activity of soil } \\
\text { dehydrogenase, } \\
\mathrm{mg} / \mathrm{mL} / \mathrm{h}\end{array}$} \\
\cline { 2 - 5 } & $\begin{array}{c}\text { After soil } \\
\text { sampling }\end{array}$ & $\begin{array}{c}\text { After } \\
\text { exposure } \\
\text { (one } \\
\text { month) }\end{array}$ & $\begin{array}{c}\text { After } \\
\text { After soil } \\
\text { sampling }\end{array}$ & $\begin{array}{c}\text { exposure } \\
\text { (one } \\
\text { month) }\end{array}$ \\
\hline 1 & 1.1 & 1.2 & 0.282 & 0.717 \\
\hline 2 & 1.7 & 2.1 & 0.354 & 2.389 \\
\hline 3 & 0.8 & 1.2 & 0.173 & 0.188 \\
\hline $\begin{array}{l}\text { Back- } \\
\text { ground } \\
\text { soil }\end{array}$ & 1.5 & 1.5 & 0.370 & 0.363 \\
\hline
\end{tabular}

During the one-month experiment, the ambiguous effect of oil on the activity of soil enzymes was revealed. It is known that, depending on the type and dose of the pollutant, the type of soil, environmental conditions, the group of soil enzymes, the duration of contamination, the enzymatic activity of soils can either increase or decrease.

The active soil respiration rate is defined as the amount of $\mathrm{CO}_{2}$ in one $\mathrm{mg}$ of soil released from a surface unit soil per hour. The results of determining the active respiration of the arctic soil are shown in Table 5 .

Table 5. The results of determination of the active respiration of the arctic soil samples

\begin{tabular}{|c|c|c|}
\hline \multirow{2}{*}{ Sample } & \multicolumn{2}{|c|}{$\begin{array}{r}\text { The active respiration of soil, } \\
\mathrm{mgCO}_{2} / \mathrm{dm}^{2} \cdot \mathrm{h}\end{array}$} \\
\cline { 2 - 3 } & After soil sampling & $\begin{array}{c}\text { After exposure (one } \\
\text { month) }\end{array}$ \\
\hline 1 & 4.34 & 6.91 \\
\hline 2 & 5.95 & 8.68 \\
\hline 3 & 0.64 & 6.11 \\
\hline Background soil & 4.66 & 4.60 \\
\hline
\end{tabular}

The results of microbiological analysis of the arctic soil are shown in Table 6 and in Figure 2.

Table 6. The results of microbiological analysis of the arctic soil samples

\begin{tabular}{|c|c|c|}
\hline Sample & Identification of the culture & $\begin{array}{c}\text { Total plate count, } \\
\text { pcs. }\end{array}$ \\
\hline \multirow{6}{*}{1} & Micromonospora aurantiaca & 4 \\
\hline & Priceomyces melossophilus & 1 \\
\hline & Azotobacter chroococcum & 3 \\
\hline & Indefined & 1 \\
\hline & Pseudomonas oleovorans & 10 \\
\hline & Indefined & 1 \\
\hline \multirow{6}{*}{2} & Novosphingobium panipatense & 1 \\
\hline & Priceomyces melissophilus & 53 \\
\hline & Indefined & 5 \\
\hline & Penicillium & 7 \\
\hline & Bacillus subtilis & 6 \\
\hline & Priceomyces melossophilus & 1 \\
\hline \multirow{3}{*}{3} & Azotobacter chroococcum & 1 \\
\hline & Penicillium & 21 \\
\hline & Indefined & 10 \\
\hline $\begin{array}{l}\text { Back- } \\
\text { ground } \\
\text { soil }\end{array}$ & $\begin{array}{l}\text { Azotobacter chroococcum } \\
\text { Penicillium } \\
\text { Indefined }\end{array}$ & $\begin{array}{l}1 \\
2 \\
5\end{array}$ \\
\hline
\end{tabular}

The microbiological composition in the background sample is quantitatively and qualitatively different from the ones of polluted arctic soils. In the latter, a predominance of oil-oxidizing species of microorganisms is noted. 
a)

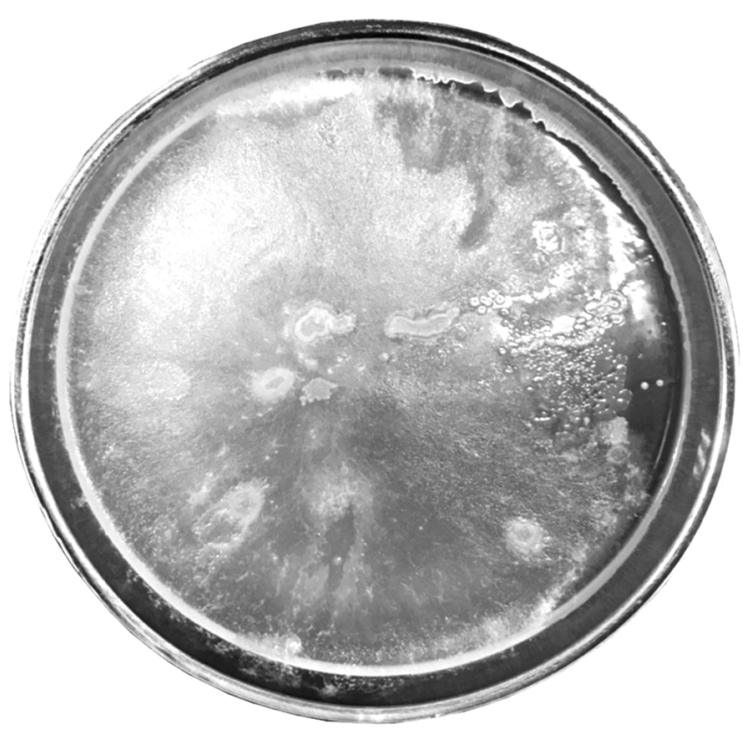

b)

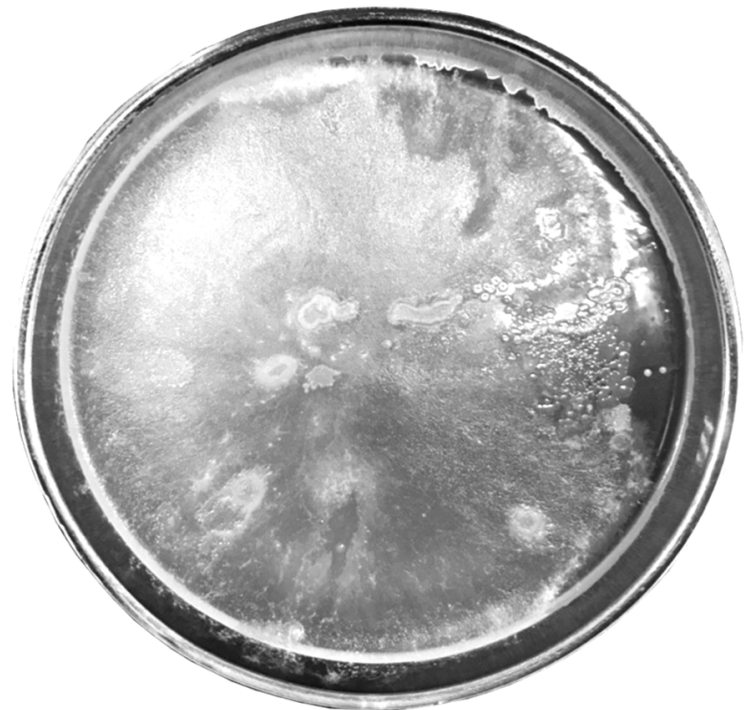

c)

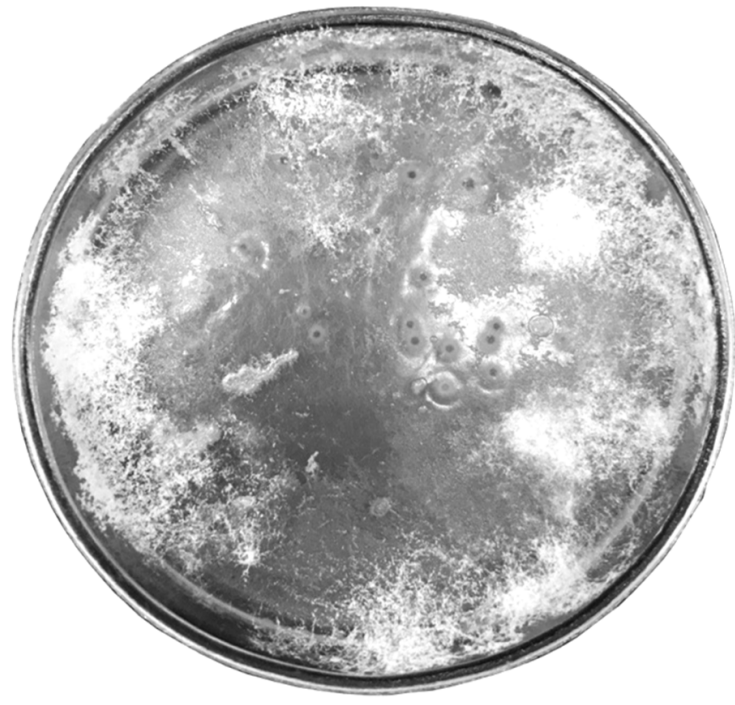

Figure 2. Microbiological analysis of the polluted arctic soil samples: $\mathrm{a}-1, \mathrm{~b}-2, \mathrm{c}-3$ respectively

\section{Discussion}

The study results demonstrated the high content of chloride-ions in the samples. The toxicity threshold, considering the analysis of water extraction from the soil is about $0.05 \%$. The high chloride-ion content in the studied samples of the arctic soil has a significant effect on the processes of nutrient removal from the soil due to leaching, compaction of the upper soil layer and swamping.

The high petroleum content in all soil samples is the result of accumulated environmental damage occurred in the research area. Comparison of the petroleum concentration with the permafrost-tundra-taiga pollution data was carried out; the approximate permissible TPH concentration in the soil, taking into account the background values, is $2,000 \mathrm{mg} / \mathrm{kg}$. The samples 1 and 3 taken in the upper layers of the soil are the most polluted: the amount of petroleum hydrocarbons exceeds the background level by 15 and 24 times, respectively. Significant oil-pollution of the arctic soil characterizes it as severely disturbed and also indicates a number of transformations in the soil: a change in the chemical composition, structure, properties, disturbance of the soil as a nutrient substrate for plants and the microorganisms. Such a quantity of oil products in the arctic soil samples is unacceptable and requires the measures to eliminate pollution and restore its original properties.

Enzymes in the soil intensify various metabolic processes and are a reliable indicator of soil biogenicity. The level of catalase activity determines the degree of soil contamination with hydrocarbons and the possibility of self-restoration from them. Dehydrogenase promotes the dehydrogenation of organic matter and is an intermediate carrier of hydrogen, thereby also providing the process of decomposition of hydrocarbons (Ismailov, 1988; Ogbolosingha et al., 2015; Kaczyńska et al., 2015). The results of the enzymatic activity and a change in the active respiration of the arctic soil in a month after exposure show a low ability of the soil to restore. It should also be noted that the experiment was carried out in laboratory conditions that did not ensure the reproduction of the conditions of the Arctic zone. The intensity of self-restoration processes decreases from less polluted to more polluted samples. This is due to the primary characteristics of the soil and a greater effect on oil-destroying microorganisms in samples of severely disturbed arctic soil.

All polluted soil samples revealed a significant number of hydrocarbon-oxidizing microorganisms: Penicillium, Azotobacter chroococcum, Bacillus subtilis, Pseudomonas oleovorans (Table 6), which is not typical for unpolluted samples of the soil. Pseudomonas oleovorans, Priceomyces melissophilus, Penicillium were the dominant microorganism cultures in the analyzed soil samples. The presence and quantitative excess of these types of microorganisms can also be considered as an indicator of negative effects on soils. Thus, the presence of such microorganisms shows the possibility of oil-contaminated soil for self-restoring in a controlled laboratory environment. 


\section{Conclusions}

Several soil quality indicators have been evaluated; the results allow for a comprehensive environmental assessment of soils in the Arctic region, including their ability to selfrestoration. The list of the diagnostic indicators suitable for the disturbed arctic soils should include such chemical indicators as the concentration of the major pollutants (oil content, concentrations of heavy metals, chloride-ions, nitrate nitrogen, phosphorus (mobile form)). The bioindicators consist of the enzymatic activity indicators, mainly oxidoreductases, determination of soil respiration and microbiological analysis with identification of microbial strains.

A direct dependency was established between the activity of oxidoreductases and the rate of decomposition of hydrocarbons. Catalase activity indicator can be recommended for enzymatic diagnosis of contaminated soils and changes in redox conditions.

The results of arctic soil samples analysis showed their low self-restoration ability and the need for remediation. Considering two main approaches of the soil remediation in the Arctic region, cleaning to an acceptable level of oil pollution and not interfering with self-restoration were under discussion.

Thus, in the presence of oil pollution above APC, it was recommended to use the following methods of remediation in the case of the particular oil-polluted soil:

- soil-washing;

- landfarming;

- bioremediation;

- air-sparging;

- reagent treatment in combination with biological methods of the remediation;

- biostimulation of self-restoration processes, selfgrowth of tolerant plants, bioaugmentation and bioventing.

However, such remediation methods as landfarming and air sparging are difficult to reproduce due to the remoteness of the territory of the remediation. Therefore, the selection of the appropriate method and technological support will be determined not only by environmental, but also economic criteria.

\section{Conflict of interest}

The authors declare that they have no known conflicts of interest.

\section{References}

Beyer, L., Huyke, W., Huttmann, S., Archegova, I., \& Titarenko, T. V. (2000). The application of microbial activity indicators for a quality evaluation of highly crude oil contaminated soils in the Russian subpolar tundra at the Arctic circle. In Contaminated Soil 2000: Proceedings of the Seventh $7^{\text {th }}$ International FZK/TNO Conference on Contaminated Soil, 1, 856-857.
Bünemanna, E. K., Bongiorno, G., Bai, Z., Creamer, R. E., De Deyn, G., Goede, R., Fleskens, L., Geissen, V., Kuyper, T. W., Mäder, P., Pulleman, M., Sukkel, W., Groenigen, J. W., \& Brussaard, L. (2018). Soil quality - A critical review. Soil Biology and Biochemistry, 120, 105-125. https://doi.org/10.1016/j.soilbio.2018.01.030

Bünemann, E. K., Mäder, P., Wohlfahrt, J., Brussaard, L., Bongiorno, G., de Goede, R., Geissen, V., Fleskens, L., Sukkel, W., Bai, Z., \& Caspari, T. (2016). Concepts and indicators of soil quality - a review (Report No. 04). SQAPER. www.iSQAPER-project.eu

Cardoso, E. J. B. N., Vasconcellos, R. L. F., Bini, D., Miyauchi, M. Y. H., dos Santos, C. A., Alves, P. R. L., de Paula, A. M., Nakatani, A. Sh., de Moraes Pereira, J., \& Nogueira, M. A. (2013). Soil health: Looking for suitable indicators. What should be considered to assess the effects of use and management on soil health? Scientia Agricola, 70(4), 274-289.

https://doi.org/10.1590/S0103-90162013000400009

Chang, W., Akbari, A., David, C. A., \& Ghoshal, S. (2018). Selective biostimulation of cold- and salt-tolerant hydrocarbon-degrading Dietzia maris in petroleum-contaminated sub-Arctic soils with high salinity. Chemical Technology and Biotechnology, 93(1), 294-304. https://doi.org/10.1002/jctb.5385

Doran, J. W., \& Parkin, T. B. (1996). Quantitative indicators of soil quality: A minimum data set. In J. W. Doran \& A. J. Jones (Eds.), Methods for assessing soil quality: Vol. 49. SSSA, Inc., Madison, Wisconsin, USA.

https://doi.org/10.2136/sssaspecpub49.c2

Ferguson, D. K., Li, C., Jiang, C., Chakraborty, A., Grasby, S. E., \& Hubert, C. R. J. (2020). Natural attenuation of spilled crude oil by cold-adapted soil bacterial communities at a decommissioned High Arctic oil well site. Science of The Total Environment, 722, 137258. https://doi.org/10.1016/j.scitotenv.2020.137258

Gerasko, L. I., Callas, E. V., Kulizhsky, S. P., \& Ogorodnikov, A. V. (2004). Fundamentals of soil science and soil geography. TSPU, Moscow (in Russian).

Guidelines for sanitary-microbiological soil research (MU 144676). (1976) (in Russian).

Ismailov, N. M. (1988). Microbiology and enzymatic activity of oil-contaminated soils. In Restoration of oil-contaminated soil ecosystems (pp. 42-56). Nauka (in Russian).

Jenkinson, D. S., Adams, D. E., \& Wild, A. (1991). Model estimates of $\mathrm{CO}_{2}$ emissions from soil in response to global warming. Nature, 351, 104-106. https://doi.org/10.1038/351304a0

Kaczyńska, G., Borowik, A., \& Wyszkowska, J. (2015). Soil dehydrogenases as an indicator of contamination of the environment with petroleum products. Water Air Soil Pollution, 226(11), 372. https://doi.org/10.1007/s11270-015-2642-9

Khabarov, A. V., \& Yaskin, A. A. (2001). Soil science. Kolos.

Kozlova, A. A. (2005). Educational practice in soil physics. Irkutsk State University (in Russian).

Kulikova, O. A. (2019). Environmental aspects of the surfactants use of for the restoration of disturbed Arctic lands (The dissertation for the degree of candidate of technical sciences). Russian Gubkin State University of Oil and Gas (NRU), Moscow (in Russian).

Lebedeva-Verba, M. P., \& Gerasimova, M. I. (2009). Micromorphology of diagnostic horizons in aridic soils (Complementary to the new classification system of soils of Russia). Eurasion Soil Science, 42(13), 1427-1434.

https://doi.org/10.1134/S1064229309130018 
Lima, A. C. R., Brussaard, L., Totola, M. R., Hoogmoed, W. B., \& de Goede, R. G. M. (2013). A functional evaluation of three indicator sets for assessing soil quality. Applied Soil Ecology, 64, 194-200. https://doi.org/10.1016/j.apsoil.2012.12.009

Medvedeva, O. E., \& Vakula, M. A. (2016). Technique of the selection of investment projects for elimination of accumulated damage to the environment in the Russian Arctic based on cost-benefit analysis. Arctic and North, 25, 94-95 (in Russian). https://doi.org/10.17238/issn2221-2698.2016.25.108

Mikhailov, I. S. (2015). Soil map of the Russian Arctic on a scale of 1: 1,000,000: Content and compilation experience. Soil Science, 49(4), 411-419 (in Russian).

Ogbolosingha, A. J., Essien, E. B., \& Ohiri, R. C. (2015). Variation of lipase, catalase and dehydrogenase activities during bioremediation of crude oil polluted soil. Journal of Environment and Earth Science, 5(14), 128-141.

Pankhurst, C. E., Doube, B. M. \& Gupta, V. V. S. R. (Eds.). (1997). Biological indicators of soil health. CABI Publishing.

Rhykerd, R. L., Weaver, R. W., \& McInnes, K. J. (1995). Influence of salinity on bioremediation of oil in soil. Environmental Pollution, 90(1), 127-130. https://doi.org/10.1016/0269-7491(94)00087-T

Stoops, G. (2003). Guidelines for analysis and description of soil and regolith thin sections. Madison, Wisconsin, USA.

USSR State Committee for Standards. (1984). Nature protection. Soils. Methods for sampling and preparation of soil for chemi- cal, bacteriological, helmintological analysis (GOST 17.4.4.0284). RussianGost (in Russian).

USSR State Committee for Standards. (1985). Soils. Methods for determination of chloride ion in water extract (GOST 2642585). RussianGost (in Russian).

USSR State Committee for Standards. (1989). Soils. Sampling (GOST 28168-89). RussianGost (in Russian).

USSR State Committee for Standards. (1998). Guidelines for quantitative chemical analysis of soils. The methodology for measuring the mass fraction of oil products in mineral, organogenic, organomineral soils and bottom sediments by IR spectrometry (PND F 16.1: 2.2.22-98). RussianGost (in Russian).

Vishnevaya, Yu. S. (2016). Assessment of the ecological state and degree of heavy metal pollution in Arctic soils. Vestnik MGOU. Series: Natural Sciences, 2, 96-104 (in Russian).

Wang, Sh., Xu, Ya., Lin, Zh., Zhang, J., Norbu, N., \& Liu, W. (2017). The harm of petroleum-polluted soil and its remediation research. AIP Conference Proceedings, 1864, 020222. https://doi.org/10.1063/1.4993039

\section{APPENDIX}

Abbreviations: AZRF - Arctic zone of the Russian Federation; APC - approximate permissible concentration; TPH - total petroleum hydrocarbons. 